\title{
Assessing availability of amino acids from various feedstuffs in dairy cattle using a stable isotope-based approach
}

\author{
X. Huang, ${ }^{1}$ K. A. Estes, ${ }^{1}$ P. S. Yoder, ${ }^{1}$ C. Wang,${ }^{2}$ N. Jiang, ${ }^{3}$ T. Pilonero, ${ }^{1}$ and M. D. Hanigan ${ }^{1 *}$ \\ ${ }^{1}$ Department of Dairy Science, Virginia Tech, Blacksburg 24061 \\ ${ }^{2}$ College of Animal Science and Technology, Zhejiang A\&F University, Hangzhou 311300, China \\ ${ }^{3}$ College of Animal Science and Veterinary Medicine, Heilongjiang Bayi Agricultural University, Daqing 163319, China
}

\section{ABSTRACT}

Nitrogen efficiency in dairy cows can be improved by more precisely supplying essential amino acids (EAA) relative to animal needs, which requires accurate estimates of the availability of individual EAA from feedstuffs. The objective of this study was to determine EAA availability for 7 feed ingredients. Seven heifers $(258 \pm 28 \mathrm{~kg}$ BW) were randomly chosen and assigned to 8 treatment sequences in a $7 \times 8$ incomplete Latin square design. Treatments were a basal diet (BD), and $10 \%$ (on a dry matter basis) of BD replaced by corn silage (CS), grass hay $(\mathrm{GH})$, alfalfa hay $(\mathrm{AH})$, dried distillers grain (DDGS), soybean hulls (SH), wet brewers grain (BG), or corn grain (CG). Total plasma AA entry rates were estimated for each EAA within each diet by fitting a 4-pool dynamic model to observed plasma, ${ }^{13} \mathrm{C}$ AA enrichment resulting from a 2 -h constant infusion of a ${ }^{13} \mathrm{C}$ algal AA mixture. Individual EAA availability from each test ingredient was determined by regression of entry rates for that AA on crude protein intake for each ingredient. The derived plasma total EAA entry rates for corn silage, grass hay, alfalfa hay, dried distillers grain, soyhulls, brewers grain, and corn grain were $30.6 \pm 3.4,27.4 \pm 3.2,31.3 \pm 3.4,37.2 \pm 3.2,26.4 \pm$ $3.2,37.8 \pm 3.2$, and $33.5 \pm 3.2 \%$ ( \pm standard error) of EAA from each ingredient, respectively. Using the previous estimate of $8.27 \%$ EAA utilization by splanchnic tissues during first pass, total rumen-undegradable protein EAA absorbed from the gut lumen was 33.4, $29.9,34.1,40.6,28.8,41.2$, and $36.5 \%$ of the EAA in each ingredient respectively.

Key words: amino acid, availability, isotope, dairy cattle

Received March 11, 2019.

Accepted August 1, 2019.

*Corresponding author: mhanigan@vt.edu

\section{INTRODUCTION}

Improving $\mathrm{N}$ efficiency of dairy production has received a lot of attention due to feed costs and environmental concerns (Külling et al., 2001; Agle et al., 2008; Bouwman et al., 2013). During the past decades, producers generally maximized milk yield to improve profit margins by overfeeding protein, which is the main cause of inefficient $\mathrm{N}$ utilization (Doepel et al., 2004; Colmenero and Broderick, 2006). The simplest strategy to optimize $\mathrm{N}$ utilization is to lower dietary protein (Kebreab et al., 2010), but this increases the risk of MP deficiency, resulting in decreased milk protein yield (NRC, 2001; Cabrita et al., 2011). Studies in monogastric animals have showed that balancing AA supply with animal requirements can improve the efficiency of N utilization (Baker, 1996; Nahm, 2002). In ruminants, optimizing $\mathrm{N}$ efficiency may be achieved by providing RUP with an AA profile that complements microbial AA flow (Ipharraguerre et al., 2005; Haque et al., 2012). However, previous work has demonstrated that AA flow from the rumen was biased when predicted with the NRC (2001) system. This model overestimates RUP flow from the rumen and underestimates microbial protein (MCP) flow (Bateman, 2005; Roman-Garcia et al., 2016; White et al., 2017a). Such bias hampers efforts to achieve a perfect match between supply and requirements.

Bateman (2005) reported that many unknown factors affect RUP content, including DMI, protein solubility, and heat denaturation. Although some studies have showed that the EAA composition of intact feed protein and of RUP did not differ (Boucher et al., 2009b; Edmunds et al., 2013), this may only be true for feedstuffs with low ruminal degradability (Boucher et al., 2009a). Paz et al. (2014) found that the AA profile of RUP was altered during a 16 -h ruminal incubation and that the extent of change varied by AA and feedstuff. Furthermore, previous studies showed the AA digestibility of RUP varied across feedstuffs and individual AA (White et al., 2017b). Therefore, using a common digestibility across EAA based on CP digestibility may 
lead to errors in predicting EAA availability (Borucki Castro et al., 2007).

Dried distillers grain, corn grain, brewers grain, soybean hulls, soybean meal, corn silage, alfalfa hay, and grass hay are widely used dietary ingredients in North American dairy rations. In 2016, total use of corn grain and soybean meal in the United States represented 66.3 and $14.7 \%$, respectively, of concentrate feeds fed to livestock and poultry (USDA, 2017). In 2016, total use of corn grain in the United States represented $66.3 \%$ of concentrate feeds fed to livestock and poultry (USDA, 2017). The exact proportions of overall feed usage represented by each are not available for dairy. According to AFIA (2017), total consumption of corn grain, soybean meal, dried distillers grain, and soybean hulls by dairy cows in 2016 was $14.73,2.58,2.43$, and 1.39 million tons, which represented approximately $68.1,11.9,11.2$, and $6.4 \%$ of concentrates fed to dairy cows, respectively. However, these estimates may be biased, as most of the other byproducts were excluded from the diet simulations. Corn silage and alfalfa hay also represent a large fraction of forages consumed by dairy cattle. For example, total usage of corn silage by U.S. dairy cattle in 2016 was 41.3 million tons (AFIA, 2017). Some studies have been conducted to investigate the digestibility of individual AA of RUP for various feed ingredients in the past decades. For example, in situ studies showed that the AA digestibility of RUP from soybean meal varied from $92.7 \%$ (Arg) to $95.3 \%$ (Thr), and the values for dried distillers grain varied from $87.4 \%$ (His) to $95 \%$ (Leu; White et al., 2017b). Van Straalen et al. (1997) indicated that the AA digestibility of RUP from soybean hulls varied from $61 \%$ (Tyr) to $85 \%$ (Arg). Taghizadeh et al. (2005) found that the AA digestibility of RUP AA varied from $60 \%$ (Arg) to $85 \%$ (Met) for corn silage, from $59 \%$ (Met) to $87 \%$ (Lys) for alfalfa, and from $76 \%$ (Thr) to $92 \%$ (Met) for corn grain. But as White et al. (2017b) stated, the current AA degradation and digestibility database is incomplete and contains inadequate experimental replication for commonly used feeds in the field. More importantly, these values were mainly from in vitro and in situ studies, which have not been fully validated against in vivo observations, and, where examined, have been found to differ from in vivo observations (Titgemeyer et al., 1989; Estes, 2017).

Determining the apparent AA digestibility for the diet or RUP in ruminants is technically difficult due largely to errors of measurement associated with sample collection and animal variation (NRC, 2001). Although in vitro digestibility may represent true values for some ingredients, they are not applicable to all ingredients (Estes et al., 2018), and thus research on intestinal availability of individual AA from feedstuffs is quite limited (Titgemeyer et al., 1989; Ipharraguerre et al., 2005). Measuring in vivo disappearance from the intestine is technically difficult and invasive, requiring surgical insertion of cannulas (Titgemeyer et al., 1989). The in vivo method of plasma AA concentration responses after an abomasal pulse dose is simpler and has been used to assess rumen-protected Met and Lys (Graulet et al., 2005; Whitehouse et al., 2016). However, it is difficult to apply to all AA in feed ingredients. Estes et al. (2018) adapted a stable isotope approach used by Maxin et al. (2013) to assess AA availability from individual feed ingredients. This method makes use of a 4 - to 8-h constant infusion of a ${ }^{13} \mathrm{C}$-labeled AA mixture derived from enriched algae to assess the plasma entry rate of each AA. Because infusions and sampling are performed via the jugular vein, measurements can be made with minimal animal preparation. Errors of determination for AA availability from each ingredient are approximately 10\% using this method, which is a large improvement over previously used methods (Titgemeyer et al., 1989).

Our hypothesis was that the stable isotope-based approach can be used to determine AA availability across various feedstuffs with high or low protein content. Additionally, extending the knowledge of AA availability to more commonly used feed ingredients will provide a basis for improvements to our feeding systems. Therefore, the objective of this study was to determine plasma EAA availability and RUP digestibility for 7 feed ingredients commonly used in dairy rations: dried distillers grain, corn grain, wet brewers grain, soybean hulls, corn silage, alfalfa hay, and grass hay.

\section{MATERIALS AND METHODS}

\section{Animals and Treatments}

All animal procedures were conducted at the Virginia Tech Kentland Dairy Farm and approved by the Virginia Tech Animal Care and Use Committee. Seven Holstein heifers $(258 \pm 28 \mathrm{~kg}$ BW $)$ were randomly selected and assigned to 8 treatments in a 7 $\times 8$ incomplete Latin square design, with 8 periods of $10 \mathrm{~d}$ each. Treatments were a high-protein basal diet (BD), and 10\% (DM basis) of BD replaced by corn silage (treatment $\mathbf{C S}$ ), grass hay $(\mathbf{G H})$, alfalfa hay $(\mathbf{A H})$, soybean hulls $(\mathbf{S H})$, dried distillers grain (DDGS), wet brewers grain (BG), or corn grain (CG; Table 1). Kentland farm of Virginia Tech (Blacksburg, VA) supplied alfalfa hay, grass hay, and corn silage, and grains were purchased from Rockingham Milling Company (Harrisonburg, VA). The BD contained a mix of corn silage, dried grass hay, soybean meal, and vitamins and minerals (Table 1 ). The MP supply of 
Table 1. Diet composition and formulated nutrients; diets were formulated for a 272-kg BW heifer with a DMI of $6.6 \mathrm{~kg} / \mathrm{d}$

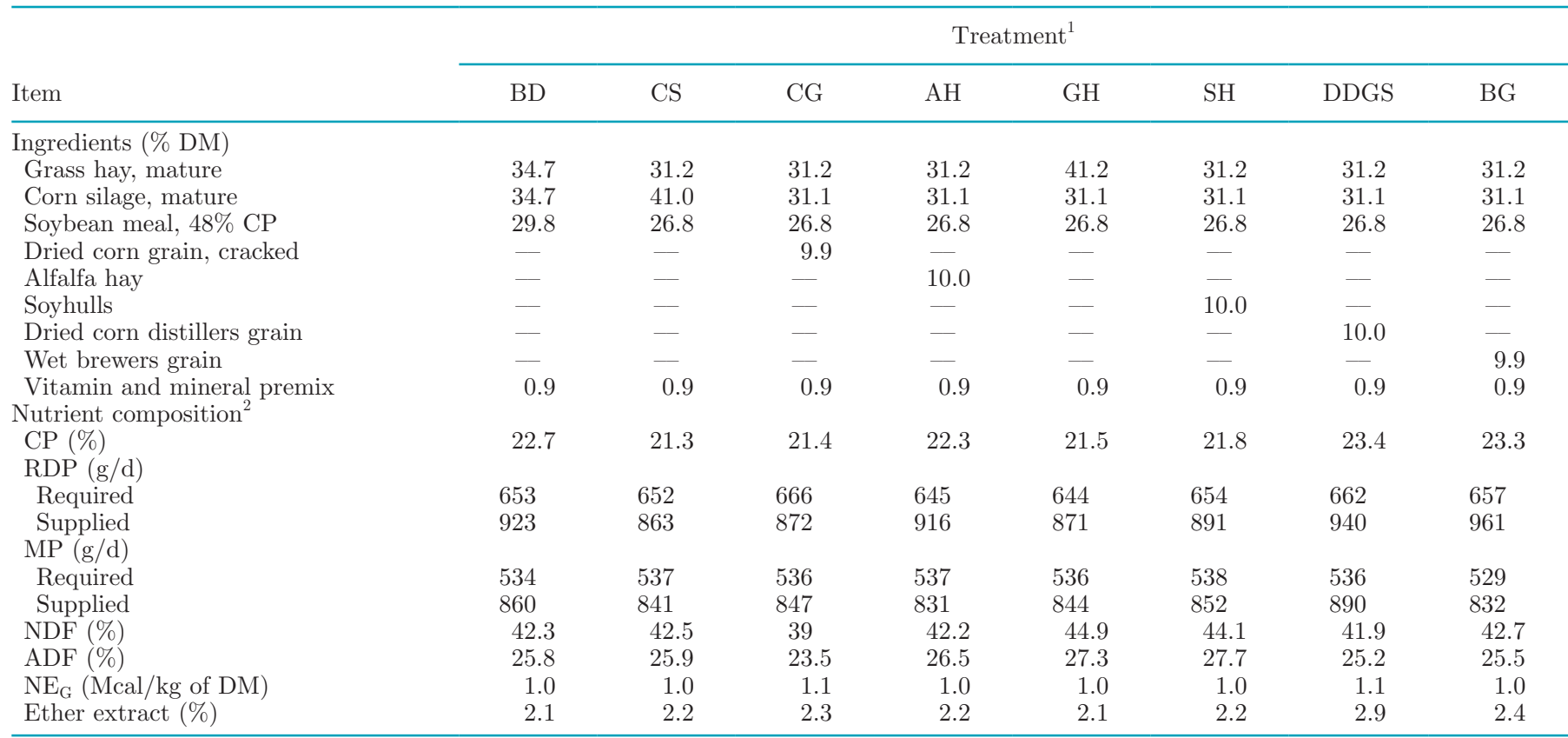

${ }^{1} \mathrm{BD}=$ basal diet; $\mathrm{CS}=90 \% \mathrm{BD}+10 \%$ corn silage $\mathrm{GH}=\mathrm{BD}+$ grass hay; $\mathrm{AH}=\mathrm{BD}+$ alfalfa hay; DDGS $=\mathrm{BD}+$ dried distillers grain; $\mathrm{SH}$ $=\mathrm{BD}+$ soybean hulls; $\mathrm{DCDG}=\mathrm{BD}+$ dried corn distillers grain; $\mathrm{BG}=\mathrm{BD}+$ wet brewers grain; $\mathrm{CG}=\mathrm{BD}+$ corn grain.

${ }^{2}$ Nutrient components were estimated from the NRC (2001).

BD was $860 \mathrm{~g} / \mathrm{d}$, which greatly exceeded NRC (2001) recommendations $(534 \mathrm{~g} / \mathrm{d})$, to ensure that microbial protein synthesis and body protein synthesis were not altered by the treatments. Animals were fed once a day ad libitum from d 1 to 8 . On d 6 , animals were moved to metabolism stalls at $0800 \mathrm{~h}$, and fed at 6-h intervals through d 8. On d 9 and 10, animals were fed every $2 \mathrm{~h}$, and feed offered was restricted to $95 \%$ of the ad libitum DMI observed for the previous $3 \mathrm{~d}$, to ensure that each meal was eaten and to minimize variation in AA absorption, according to Estes et al. (2018).

On d 7 to 9 of each period, spot fecal samples were collected every $6 \mathrm{~h}$, with the collection time rotating forward $2 \mathrm{~h}$ on the second day of collection and $4 \mathrm{~h}$ on the third day of collection. Samples were stored at $-20^{\circ} \mathrm{C}$ until analysis. Feed and refusal samples were collected between 0700 and $0800 \mathrm{~h}$ daily from d 6 through 10 and, at the end of the infusion, dried at $55^{\circ} \mathrm{C}$ for 72 $\mathrm{h}$ and stored for further analysis.

On d 8 of each period, each heifer was fitted with 2 jugular catheters in the same side, as described by Estes et al. (2018). In short, the infusion catheter (90 $\mathrm{cm} \times 2.03 \mathrm{~mm}$ internal diameter; Braintree Scientific Inc., Braintree, MA) tip was placed approximately 40 $\mathrm{cm}$ downstream of the tip of the sampling catheter (13 $\mathrm{cm} \times 1.6 \mathrm{~mm}$ internal diameter; Jorvet, Loveland, CO) to ensure infusate circulation through the circulatory system before blood sampling. Catheters were placed on alternate sides of the neck in successive periods. On d 10, animals were given a constant jugular infusion of $0.2 \mathrm{~g}$ of a sterile ${ }^{13} \mathrm{C}$-labeled algal AA mix dissolved in $100 \mathrm{~mL}$ saline $\left(\mathrm{U}_{-}{ }^{13} \mathrm{C}, 97\right.$ to $99 \%$ enriched; Cambridge Isotope Laboratories, Andover, MA) over a 2-h period using clinical infusion pumps (LifeCare 5000, Abbott Laboratories, North Chicago, IL). Infusions were initiated at $1100 \mathrm{~h}$ and ended at $1300 \mathrm{~h}$. Blood samples ( 8 to $10 \mathrm{~mL}$ each) were collected at $-15,15,30,45$, $60,75,90,105,120,135,150,165,180,195,210$, and 240 min relative to the start of the infusion and stored on ice until processing. Plasma was prepared from the blood samples by centrifugation for 15 min at $1665 \times$ $g$ within $4 \mathrm{~h}$ of sampling. Plasma was stored at $-20^{\circ} \mathrm{C}$ until further analysis.

\section{Sample Analysis}

Feed and Fecal Sample Analysis. Dried TMR and fecal samples were pooled by animal and period and ground to $2 \mathrm{~mm}$ (Wiley Mill, Thomas Scientific, Swedesboro, NJ). Duplicate subsamples (10 g of TMR or $5 \mathrm{~g}$ of feces) were placed in $10 \times 20$-cm Dacron bags with $50 \pm 15-\mu \mathrm{m}$ pore size (Ankom, Macedon NY); the ratios of sample size to surface area were 25 and $12.5 \mathrm{mg} / \mathrm{cm}^{2}$ specifically (NRC, 2001). The bags were incubated in the rumen of 2 cows (fed the BD diet; one replicate in each animal) for $12 \mathrm{~d}$ to determine 
indigestible NDF (iNDF) content (Estes et al., 2018). The NDF content of the residue was determined using amylase and an Ankom Fiber Analyzer 200, and iNDF was assumed to be the residue after Ankom digestion. Dry, ground feed ingredients (25 to $40 \mathrm{mg}$ ) and fecal samples were analyzed for $\mathrm{N}$ content by combustion using a Vario EL cube analyzer (Elementar, Germany). Results were used to calculate fecal DM output and total-tract apparent $\mathrm{N}$ digestibility as described by Cochran et al. (1986).

Ruminal Protein Degradation of Feed Ingredients. Two subsamples of feed ingredients were sent to Cumberland Valley Analytical Services (Waynesboro, PA) for in vitro rumen and intestinal digestibility analysis of protein (MSPE package). Another subsample was used for in situ ruminal protein degradation analysis. The same 2 cows used for TMR and fecal sample incubation were used here. All ingredients (SBM, CS, $\mathrm{CG}, \mathrm{AH}, \mathrm{GH}, \mathrm{SH}$, and DDGS) were ground to $2 \mathrm{~mm}$, $10 \mathrm{~g}$ of which were weighed into Dacron bags $(10 \times$ $20 \mathrm{~cm}, 50-\mu \mathrm{m}$ pore size; Ankom, Macedon, NY), and bags containing samples were incubated in the rumen for $0,3,9,12,15,24,36,48,72,96$, and $108 \mathrm{~h}$. Upon removal from the rumen, samples were rinsed in cold water and then washed through the delicate cold cycle in a washing machine without detergent and frozen at $-20^{\circ} \mathrm{C}$ followed by freeze drying. Twenty-five to forty $\mathrm{mg}$ of ground feed ingredients were used for nitrogen analysis as described above.

The insoluble but degradable fraction (B) and insoluble and undegradable fraction $(\mathrm{C})$ of each ingredient and the rate of $\mathrm{N}$ degradation $\left(\boldsymbol{K}_{\boldsymbol{d}}\right)$ were determined by fitting the following model, a modification of that described by Ørskov and McDonald (1979), to the data:

$$
\mathrm{N}(\mathrm{t})(\% \text { of initial })=\mathrm{C}+\mathrm{B} \times e^{\left[-K_{d} \times \mathrm{t}\right]} .
$$

The soluble fraction (A) was calculated from the modelderived $\mathrm{B}$ and $\mathrm{C}$ fractions as follows:

$$
\mathrm{A}=100-\mathrm{B}-\mathrm{C},
$$

where $\mathrm{N}(\mathrm{t})$ was the $\mathrm{N}$ remaining at time $\mathrm{t}$ (\% of initial $\mathrm{N}$ content). The A fraction (\% of initial $\mathrm{N}$ content) represents $\mathrm{N}$ escaping from the bag at time 0 , which mostly reflects soluble $\mathrm{N}$ but may include some very small particles. The $\mathrm{C}$ fraction (\% of initial $\mathrm{N}$ content) is the nondegradable $\mathrm{N}$ at t $=108 \mathrm{~h}$, and $K_{d}$ represents the rate of $\mathrm{B}$-fraction $\mathrm{N}$ loss from the bag $\left(\mathrm{h}^{-1}\right)$. We attempted to introduce lag time; however, this made no difference and thus was removed.

Plasma Sample Analysis. All plasma samples were deproteinized by addition of sulfosalicylic acid
(8\%, wt/vol) followed by centrifugation at $1,600 \times g$ for $15 \mathrm{~min}$ at $4^{\circ} \mathrm{C}$. To measure the ${ }^{13} \mathrm{C}$-labeled $\mathrm{AA}$, deproteinized samples were desalted by ion exchange chromatography (BioRad Resin AG 50W-X8*, 100 to 200 mesh; Bio-Rad, Hercules, CA) and eluted using ammonium hydroxide $(2 \mathrm{~N})$ into silanized glass vials, as described by Calder et al. (1999). Desalted samples were freeze-dried and derivatized as described by Walsh et al. (2014). Measurements of isotopic ratios of ${ }^{13} \mathrm{C}$ labeled AA were performed using an isotope-ratio mass spectrometer coupled to a GC by a combustion oven (Thermo Fisher Scientific, Waltham, MA).

\section{Amino Acid Entry Rate Derivation}

All modeling work was completed in R Studio (version 1.0.143) with R 3.2.1 (R Core Team, Vienna, Austria), using the 4-pool dynamic model described by Estes et al. (2018). In short, state variables were total AA in fast $\left(\mathrm{QAA}_{\text {Fast }}\right)$ and slow turnover pools $\left(\mathrm{QAA}_{\text {Slow }}\right)$ and labeled $\mathrm{AA}$ in fast $\left(\mathrm{QAAi}_{\text {Fast }}\right)$ and slow turnover pools $\left(\mathrm{QAAi}_{\text {Slow }}\right)$. The fast turnover pool is thought to represent blood, interstitial, and cytoplasmic free AA but also likely includes some protein with short half-lives (i.e., less than $30 \mathrm{~min}$ ), whereas the slow turnover pool should only represent protein-bound AA. Estes et al. (2018) indicated that the size of the slow turnover pool cannot be accurately estimated with a 2 -h infusion, resulting in underestimates of plateau and overestimates of total AA entry rates. In the current study, we were also unable to solve for stable slow turnover rates, which reduces the accuracy of the plateau estimate (Figure 1), likely resulting in underestimated AA incorporation into the slow turnover pool and overestimated AA entry rates. However, the bias was accommodated in the intercept of the regression model that was fit across the treatments to derive the proportion of feed AA appearing in blood and, thus, was not problematic. We did not adopt the longer infusion time recommended by Estes et al. (2018), solely because the animal work for this study was completed before the Estes et al. (2018) work was completed. Because the model explicitly represents exchange of AA with body tissue, the derived AA entry rates represent only absorption (EAA) or absorption plus de novo synthesis (NEAA) minus loss of AA to splanchnic catabolism during the first pass.

Following initial fits of the model to observed data, residuals outliers were checked, and, if studentized residuals exceeded 2 in absolute value, the sample was removed, which was the case for $14 \%$ of the data set. These outliers were generally also visually apparent when the observed data were plotted with the predicted values, as the data represented a repeated sampling 


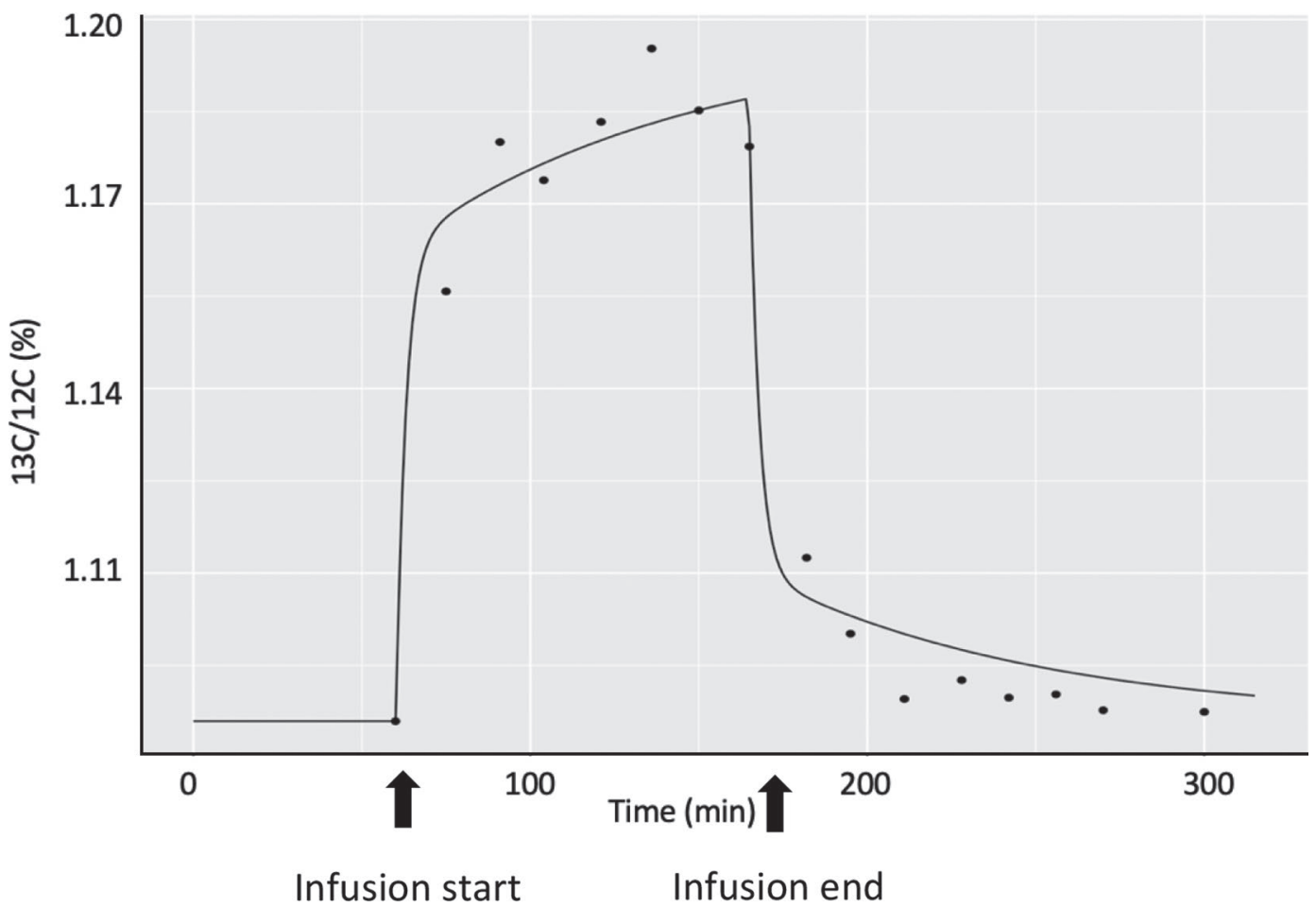

Figure 1. Predicted and observed Leu isotopic ratios versus infusion time for 1 infusion. $13 \mathrm{C} / 12 \mathrm{C}$ refers to the ratio of $13 \mathrm{C}$ labeled AA to nonlabeled AA.

sequence in time, and thus deviations from the pattern in time were clearly evident.

The modeled AA entry rates were used to derive fractional availability values (g AA appearing in plasma/g $\mathrm{CP}$ consumed) for each test ingredient by regression, as described by Estes et al. (2018). In Estes et al. (2018), dietary RDP was added to accommodate nutrient entry rates derived from the basal diet, excluding soybean meal and MCP, which varied when ruminally fermentable soybean meal was replaced by post-ruminal infusions of casein and EAA. In our study, substitutions were for $\mathrm{BD}$, and all treatment diets had RDP that greatly exceeded NRC (2001) requirements, negating the need to represent potential changes in MCP using RDP.

\section{Statistical Analysis}

Statistical analysis was conducted in $\mathrm{R}$ Studio (version 1.0.143) with R 3.2.1. Data were analyzed using the mixed model function lmer in the lme4 package of $\mathrm{R}$ (version 3.4.3). Dry matter intake, fecal output, total-tract apparent $\mathrm{N}$ digestibility, and plasma AA entry rates were analyzed using the following model:

$$
Y_{i j k}=\mu+\text { Diet }_{i}+\text { Period }_{j}+\text { Cow }_{k}+e_{i j k}
$$

where $Y_{i j k}=$ dependent variable, $\mu=$ population mean of $Y$, Diet $_{i}=$ fixed effect of diet [degrees of freedom $(\mathrm{df})=7]$, Period $_{j}=$ random effect of period $(\mathrm{df}=7)$, and $C o w_{k}=$ random effect of cow $(\mathrm{df}=6)$. Main effects were declared significant at $P \leq 0.05$, and denominator degrees of freedom for all tests were adjusted using the Kenward-Roger option. Outliers were checked, and, if studentized residuals exceeded 2 in absolute value, the sample was removed, which was the case for approximately $5 \%$ of the data set. When main effects were significant, post-hoc testing was conducted. The lsmeansLT function of the lmerTest package was used with Kenward-Roger option and Tukey adjust for estimation of least squares means, and the difflsmeans function of the lmerTest package with Tukey adjust was used for separation of means $(P<0.05)$.

\section{RESULTS AND DISCUSSION}

All 7 animals completed the trial. An important assumption of this study was that the high-CP diets exceeded requirements for MCP synthesis and body protein accretion across treatments, so that these processes remained constant across treatments. The $\mathrm{CP}$ content of BD was $22.7 \%$, which was a little higher than our formulation goal of $20 \%$. Both BG $(22.8 \%)$ and DDGS (22.8\%) had higher CP content compared 
with BD, whereas AH (21.7\%), CG (20.8\%), GH (21.1\%), SH (21.2\%), and CS (20.8\%) had lower CP content, which was anticipated, given the different $\mathrm{CP}$ contents of replacement ingredients. All of them greatly exceeded NRC (2001) requirements for RDP and MP, which achieved our formulation goal.

Our objective was to assess individual AA availability from various feed ingredients. However, this is generally restricted to EAA, as NEAA can be synthesized by the animal, which prevents derivation of a unique estimate of absorbed entry. Derived NEAA entry rates from this study had large standard errors, which indicated that post-absorptive synthesis was variable across treatments and animals, although they were well determined in our previous study that used high-protein ingredients (Estes et al., 2018). Therefore, only EAA are discussed in this report. In addition, histidine results were near baseline and quite variable due to the AA derivatization method used and thus were excluded. Amino acids with polar or charged side chains, such as histidine and serine, generally had lower recovery from alkyl chloroformates (Walsh et al., 2014).

\section{In Situ and In Vitro Protein Degradation for Test Ingredients}

All feed ingredients were tested for protein fractions by using in situ and in vitro methods. Although soybean meal was not tested in vivo, the in vitro and in situ results would still be useful as a reference to future in situ and in vitro work. Ruminal $\mathrm{N}$ digestion results from the 108-h incubation are summarized in Table 2 and Figure 2. Fraction A represents soluble $\mathrm{N}$ and $\mathrm{N}$ in particles smaller than $50 \mu \mathrm{m}$, which can escape from the nylon bag. The A fraction (58.4\%) of DDGS greatly exceeded values reported by Kleinschmit et al. $(2007 ; 15.9$ to $19.7 \%$ ) and by Mjoun et al. (2010; 11.1 to $18.4 \%$ ). The difference might be related to the amount of solubles added to grains according to Cao et al. (2009), who found a linear increase in fraction A when solubles in dried distillers grain increased. Soybean meal, soyhulls, and corn silage also showed higher A fractions compared with NRC (2001). Increased small-particle loss might be partially caused by sample preparation (grinding) or bag wash (machine wash), and can result in an overestimation of the $\mathrm{A}$ fraction (Michalet-Doreau and Ould-Bah, 1992). For example, the dry-grinding process would cause fracture of seed kernels and release protein as a fine powder. The extent of such loss can be determined (Maxin et al., 2013) and used to correct the data. In the current study, we machine-washed the bags, which removed bacteria but also might enhance the escape of small particles. These limitations have been noted as potentially contribut- ing to low repeatability of the mobile bag technique within (Setälä, 1983; Madsen and Hvelplund, 1985; Michalet-Doreau and Cerneau, 1991) and across laboratories (Oldham, 1987). Compared with the soluble protein from in vitro evaluation, the A fraction from in situ evaluation was also much higher, which further indicated particle loss from bags.

The $K_{d}$ is affected by many factors, including particle size and protein structure (NRC, 2001). Smaller particle size increases the surface area per unit of mass and thus the rate of degradation. Therefore, the higher rate of degradation for soybean meal, soyhulls, and corn grain compared with NRC may be indicative of reduced particle size, which was consistent with our observations of greater A fractions. The heat processing of dried distillers grain makes it more resistant to ruminal degradation (NRC, 2001; Doiron et al., 2009; Mjoun et al., 2010), which was consistent with its low $K_{d}$. The potentially degradable CP (fraction B) was low for soybean meal, corn silage, soyhulls, and distillers grain compared with NRC (2001), which was consistent with their high A fraction content. Fraction $\mathrm{C}$ is the nondegradable $\mathrm{N}$. The fraction $\mathrm{C}$ value may be related to heat processing of the protein, which can vary widely within feedstuffs (Kleinschmit et al., 2007; Mjoun et al., 2010). For example, the degradation of individual AA in corn silage during 12-h rumen incubation varied from 19 (Taghizadeh et al., 2005) to $71 \%$ (van Straalen et al., 1997). In the current study, the rumen protein degradation parameters of dry hays (alfalfa hay and grass hay) were more consistent with NRC (2001), which was expected, considering their small variations in processing and protein structures (Janicki and Stallings, 1988).

The calculated RUP for soybean meal, distillers gain, soyhulls, corn grain, and corn silage were all lower than values from NRC (2001) and previous studies (Paz et al., 2014), which is consistent with larger A fractions and smaller B and C fractions in the current work. The differences among studies could be caused by variability in feedstuff composition or feed and sample processing (Maxin et al., 2013). Compared with in situ and NRC values, the RUP results from in vitro testing were much greater for all ingredients except soybean meal and grass hay. This is due primarily to reduced soluble protein, suggesting that particle loss from the bags was a problem. However, we still found significant deviations in RUP estimates from the in vitro evaluations compared with the NRC value. This may be because the in vitro method cannot mimic the bioenvironment of the rumen; for example, a single incubation time may be too short, or ruminal microbes may be less active in the incubation flask, which likely leads to underestimation of RDP and overestimation of RUP. Regardless of the 
reason for the differences among methods, the variation across methods is clear.

\section{Apparent Total-Tract Digestibility of $\mathrm{N}$}

Feed intake, fecal output, and apparent total-tract digestibility observations are summarized in Table 3. The average DMI was $6.68 \pm 0.17 \mathrm{~kg}$, which was not significantly affected by treatments. Zhang et al. (2017) also observed that high-CP heifer diets did not affect DMI. The $\mathrm{N}$ intake of $\mathrm{BD}$ and DDGS were higher than those of CS, CG, GH, and SH but not significantly different from $\mathrm{AH}$ and $\mathrm{BG}$. The total-tract apparent $\mathrm{N}$ digestibility was not significantly different among treatments, with an average value of $63.1 \%$. Anderson et al. (2015) indicated that increasing DDGS in heifer diets from 30 to $50 \%$ increased total-tract $\mathrm{CP}$ digestibility. In this study, we did not observe significant differences in $\mathrm{N}$ digestibility among treatments, likely due to small differences in $\mathrm{N}$ intake or lack of precision of the measurement.

\section{Plasma Entry Rates of Individual EAA}

The standard errors of entry rates for EAA were less than $10 \%$ of estimated values (Table 4 ), which is consistent with Estes et al. (2018). The estimated EAA entry rates were not significantly different among treatments, which is consistent with NRC prediction (Table 4) of no differences among treatments in EAA flow to the small intestine. Compared with NRC estimated duodenal digestible AA flows, the derived AA entry rates were much greater, which was also observed by Estes et al. (2018) using this prediction model. Although the NRC model estimates of EAA flow from the rumen contain as much as $50 \%$ errors of prediction (Bateman et al., 2001), they clearly are not in error by 2 - or 3-fold. As discussed by Estes et al. (2018), this likely reflected inaccurate estimates of isotope incorporation into slow-turnover body protein pools during a 2 -h infusion. Hanigan et al. (2009) was able to describe mammary-tissue free AA, fast-turnover protein-bound AA, and slow-turnover protein-bound AA, using long-term infusions of several $\mathrm{AA}$, and found that the fractional incorporation of Leu, Met, Phe, and Val into total mammary tissue protein ranged from a low of $59 \%$ per day for Met to $86 \%$ per day for Val. Lower-activity tissues such as muscle likely would have much lower rates of incorporation and would still be significant isotope sinks over several days, thus explaining the significantly greater estimates of plasma entry versus NRC-predicted duodenal digestible flow rates. For example, Garlick et al. (1980) reported that the fractional rates of protein synthesis in muscle of young male rats ranged from 16.9 to $21.3 \%$ per day, whereas in active tissues such as viscera synthesis rates were as high as $119.2 \%$ per day. Hanigan et al. (2009) also indicated that the Phe turnover rate in goat mammary glands averaged $131 \%$ per day. Such bias was expected and was removed when solving for differences between ingredients and BD (Table 4). Because all

Table 2. In situ evaluation of test ingredients during a 108-h ruminal incubation and in vitro evaluation from commercial test (mean \pm SE)

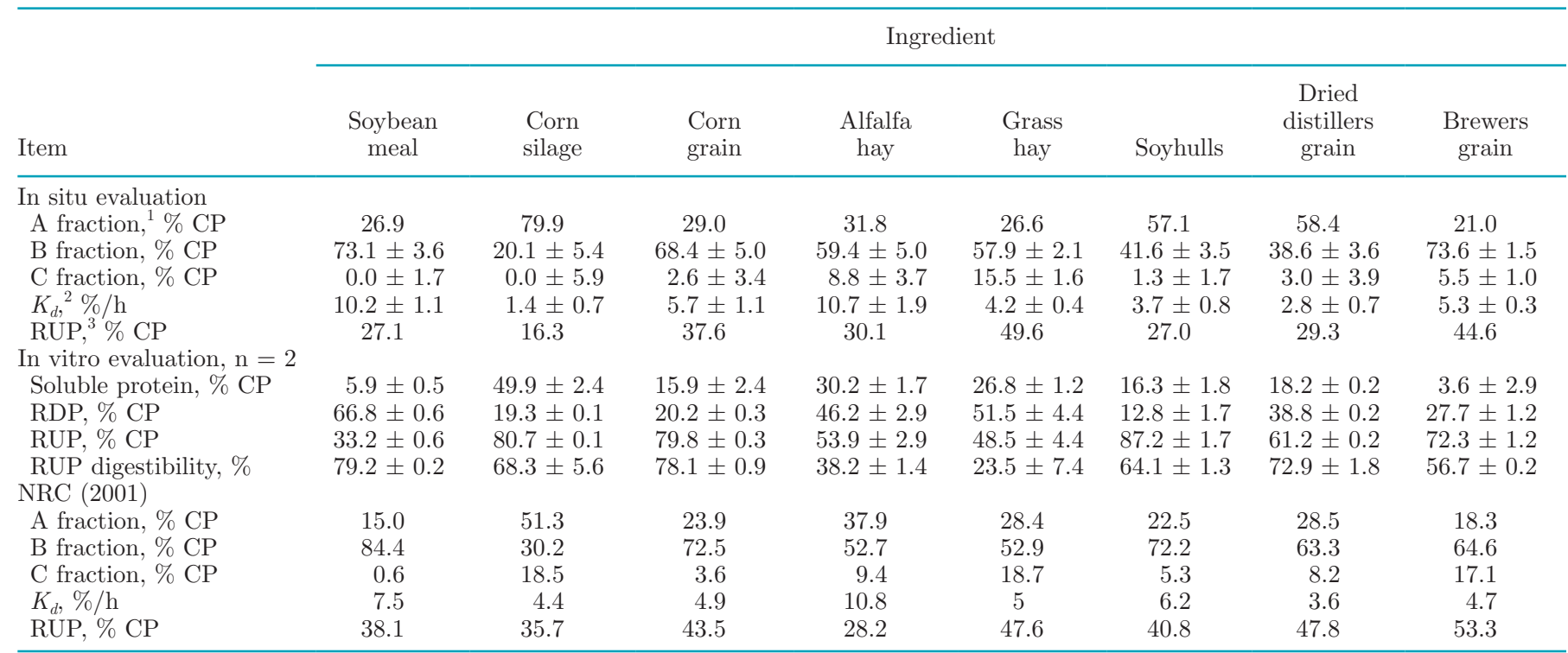

${ }^{1}$ Defined as $100-\mathrm{B}-\mathrm{C}$.

${ }^{2}$ Rate of nitrogen degradation.

${ }^{3}$ Predicted with an assumed passage rate of $6 \% / \mathrm{h}$ (NRC, 2001). 
treatments had the same proportional replacement of $\mathrm{BD}$, the expected entry rate coefficient for BD should represent the RUP from $\mathrm{BD}$ plus $\mathrm{MCP}$ contributions to EAA entry plus any bias associated with entry estimates due to loss of label in the slow turnover pool.
The plasma AA entry associated with each ingredient was derived from the dietary entry rates (Table 5), with mean standard error of the estimates of $0.37 \%$ of $\mathrm{CP}$ across the EAA and ingredients, which represented a relative error of $32 \%$. The absolute error was less than
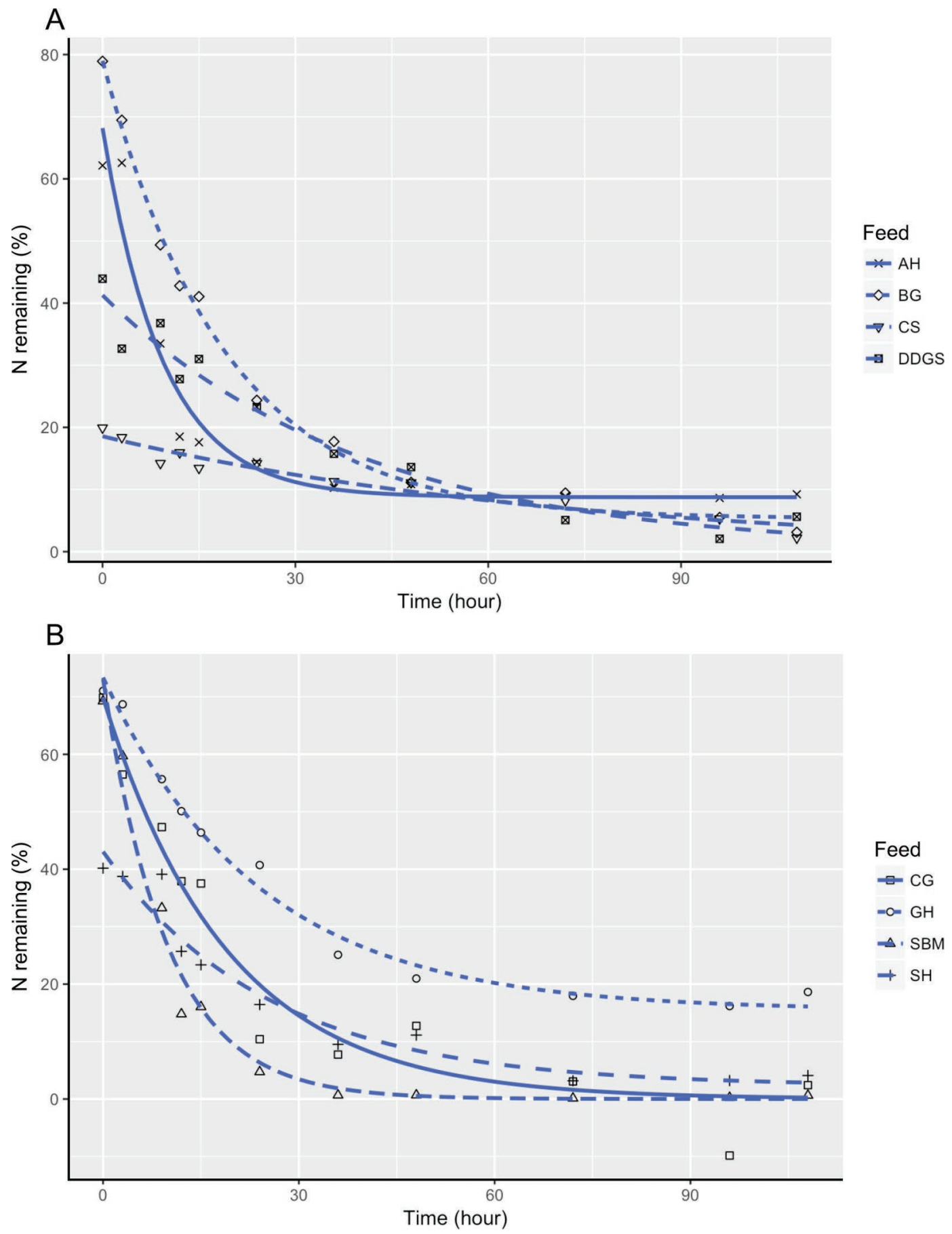

Figure 2. Observed and predicted in situ protein degradation for the test ingredients $(\mathrm{AH}=$ alfalfa hay, $\mathrm{BG}=$ wet brewers grain, $\mathrm{CS}=$ corn silage, DDGS = dried distillers grain, $\mathrm{CG}=$ corn grain, $\mathrm{GH}=$ grass hay, $\mathrm{SH}=$ soybean hulls) and soybean meal (SBM). (A) Observed and predicted in situ protein degradation for AH, BG, CS, and DDGS. (B) Observed and predicted in situ protein degradation for CG, GH, $\mathrm{SBM}$, and $\mathrm{SH}$. 
Table 3. Least squares means for feed intake and fecal output of DM and N and total-tract apparent digestibility

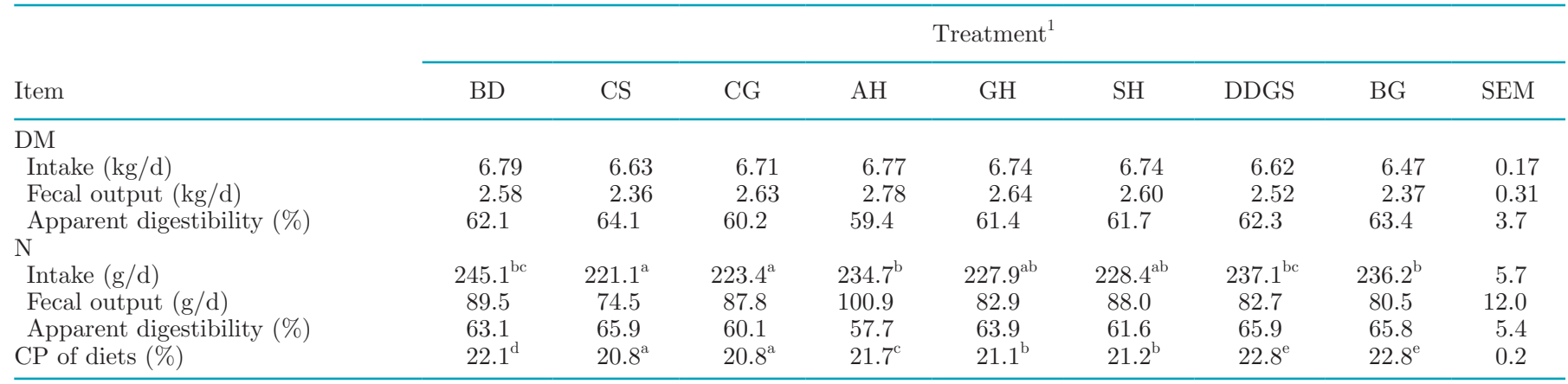

${ }^{\mathrm{a}-\mathrm{e}}$ Least squares means within a row with different superscripts are considered significantly different $(P<0.05)$.

${ }^{1} \mathrm{BD}=$ basal diet; $\mathrm{CS}=90 \% \mathrm{BD}+10 \%$ corn silage; $\mathrm{GH}=\mathrm{BD}+$ grass hay; $\mathrm{AH}=\mathrm{BD}+$ alfalfa hay; DDGS $=\mathrm{BD}+$ dried distillers grain; $\mathrm{SH}$ $=\mathrm{BD}+$ soybean hulls; $\mathrm{BG}=\mathrm{BD}+$ wet brewers grain $; \mathrm{CG}=\mathrm{BD}+$ corn grain

the mean of $0.41 \%$ of CP reported by Estes et al. (2018), however, because ingredients in the current work generally had lower CP content (DDGS vs. blood meal) and the relative error was greater than the $14 \%$ reported in the prior work. When relative errors (percent of SE to mean estimates) were compared across EAA, they were the greatest for Phe and Met, reflecting the low proportions of these AA in our test ingredients. When the average standard errors of estimated plasma AA entry rates were compared across ingredients, the low-CP ingredients, corn silage $(49 \%)$, corn grain $(45 \%)$, grass hay $(46 \%)$, and soyhulls (39\%), had greater standard errors than those with greater CP: alfalfa hay (23\%), brewers grain (13\%), and distillers grain (15\%), likely due to the differences in proportions of protein contributed by test ingredients. For example, the proportion of total dietary protein contributed by each ingredient was $4.6,5.1,5.8,6.4,8.4,12.2$, and $13.1 \%$ of $\mathrm{CP}$ for corn silage, corn grain, grass hay, soyhulls, alfalfa hay, brewers grain, and distillers grain, respectively. The correlation between the SE of estimated AA entry rates and protein contribution of test ingredients showed that the dietary true protein proportion contributed by the test ingredient should not be less than $12.1 \%$ to obtain results with standard errors less than $15 \%$ on a relative basis.

\section{Individual EAA Availability from In Vivo Evaluations of Test Ingredients}

The model-derived EAA entry rates (\% of $\mathrm{CP}$ ) for Ile, Leu, Lys, Met, Phe, Thr, and Val for each ingredi-

Table 4. Least squares means of plasma entry rates $(\mathrm{g} / \mathrm{d})$ for each treatment derived from isotope dilution model and digestible duodenal AA flow predicted by the NRC (2001) model at observed DMI

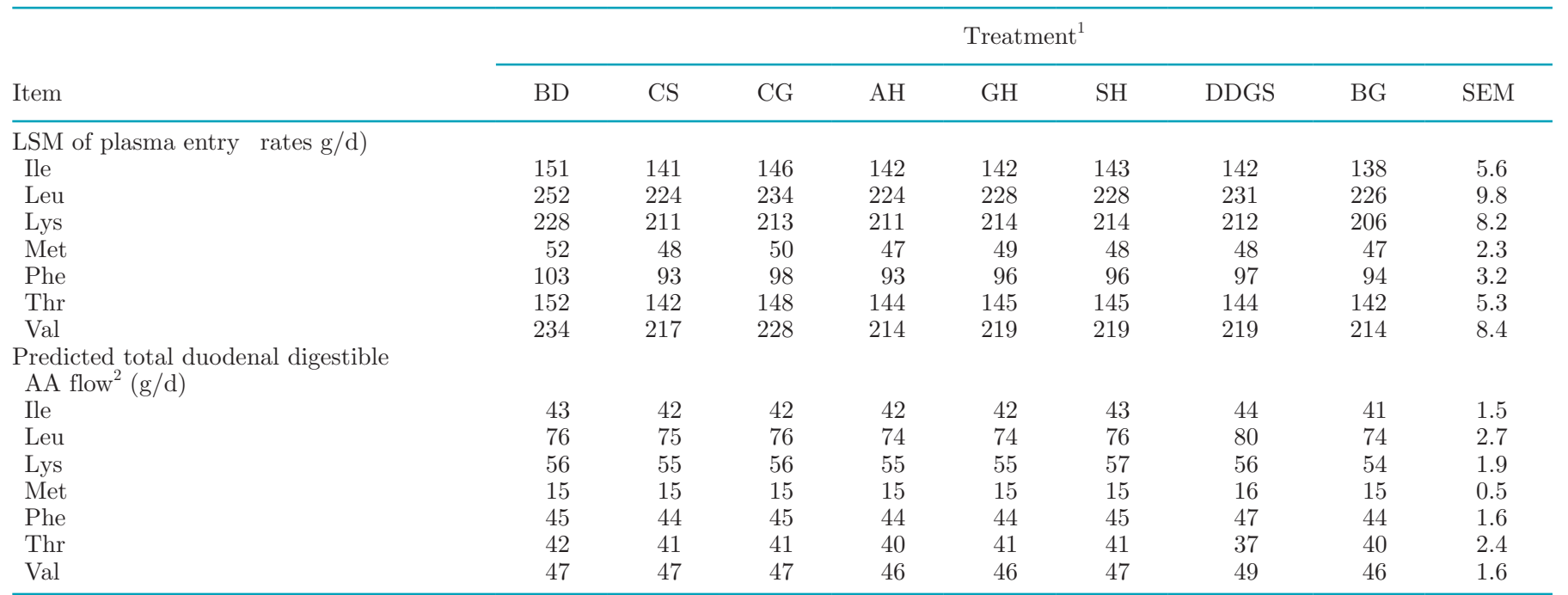

${ }^{1} \mathrm{BD}=$ basal diet; $\mathrm{CS}=90 \% \mathrm{BD}+10 \%$ corn silage; $\mathrm{GH}=\mathrm{BD}+$ grass hay; $\mathrm{AH}=\mathrm{BD}+$ alfalfa hay; $\mathrm{DDGS}=\mathrm{BD}+$ dried distillers grain; $\mathrm{SH}$ $=\mathrm{BD}+$ soybean hulls; $\mathrm{BG}=\mathrm{BD}+$ wet brewers grain $; \mathrm{CG}=\mathrm{BD}+$ corn grain .

${ }^{2}$ Total AA flow at observed DMI predicted by the NRC (2001) model. 
ent were used to estimate AA availability (\% ingredient AA), assuming that the loss of EAA during first pass through the splanchnic bed was the same as that reported by Estes et al. (2018), calculated based on observed plasma AA availability of infused casein and casein AA digestibility reported by (Rutherfurd and
Moughan, 1998; Table 5). The results indicated that AA availability varied across individual AA and feed ingredients, from $18.1 \%$ of ingredient AA for Leu to $49.6 \%$ for Met in corn silage; from $18.4 \%$ for Val to $39.4 \%$ for Phe in grass hay; from $25.2 \%$ for Leu to $50.4 \%$ for Met in alfalfa hay, from $23.8 \%$ for Thr to

Table 5. Plasma EAA entry rates for Ile, Leu, Lys, Met, Phe, Thr, and Val, and availability for each ingredient

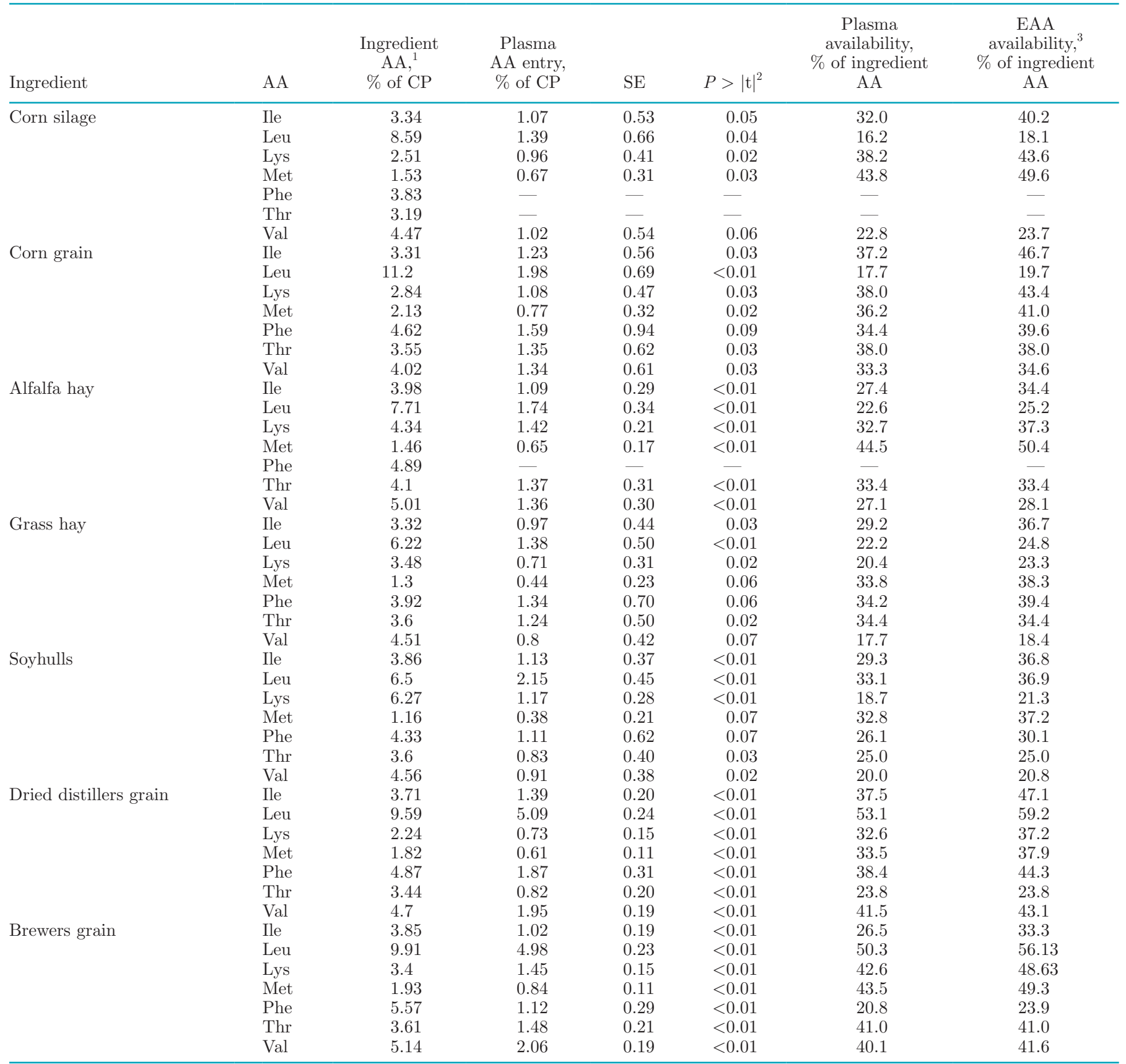

\footnotetext{
${ }^{1} \mathrm{AA}$ concentrations of ingredients were from NRC (2001).

${ }^{2}$ Test of plasma AA entry different from 0 .

${ }^{3}$ Values calculated from AA plasma availability and AA first-pass utilization by gut tissue during absorption (Rutherfurd and Moughan, 1998; Estes et al., 2018).
} 
$59.2 \%$ for Leu in distillers grain; from $20.8 \%$ for Val to $27.2 \%$ for Met in soyhulls, from $23.9 \%$ for Phe to $56.1 \%$ for Leu in brewers grain, and from $19.7 \%$ for Leu to $46.7 \%$ for Ile in corn grain. Research on AA availability of these 7 feed ingredients is limited; thus, some calculations were undertaken to make direct comparisons. For example, Taghizadeh et al. (2005) investigated the rumen degradation and intestine digestibility of AA in corn silage, corn grain, and alfalfa hay in steers using mobile bags, based on which the AA availability was calculated to vary from $12 \%$ for Met to $26 \%$ for Lys in corn grain, from $16 \%$ for Lys to $25 \%$ for Tyr in corn silage, and from $22 \%$ for Leu to $25 \%$ for Lys in alfalfa hay. Compared with current results, Taghizadeh et al. (2005) had smaller values and variation across individual AA. The potential reason for reduced estimates might be that the nylon bags created a barrier between feedstuffs and chyme, which can cause underestimation of nutrient digestibility. In addition, failure to treat the mobile nylon bags with abomasal pepsin- $\mathrm{HCl}$ might also cause the lower values found by Taghizadeh et al. (2005). Another potential explanation for the differences is that a 12-h ruminal incubation, as used by Taghizadeh et al. (2005), might not reflect real rumen retention time. Varvikko and Vanhatalo (1991) found that a 16-h rumen incubation was too short for forage. However, the AA availability calculated using nylon bags by van Straalen et al. (1997) ranged from $24 \%$ for Tyr to $37 \%$ for Met, which was greater than the values reported by Taghizadeh et al. (2005). Other possible reasons include variation in feed sources. Mjoun et al. (2010) reported absorbable AA ( $\mathrm{g} / \mathrm{kg}$ of $\mathrm{CP}$ ) supplied by distillers grain RUP as well as the AA composition of the ingredient. The AA availabilities were calculated to range from $19 \%$ for Ile to $40 \%$ for Phe. Paz et al. (2014) reported that AA availability varied from $14 \%$ for Lys to $31 \%$ for Leu in low-fat DDGS. Previous results showed that AA availability varied among different distillers grain sources, which was also reported by Kleinschmit et al. (2007). Usually grass hay is not used as a major source of protein; thus, there is limited AA digestibility data for it. Borucki Castro et al. (2007) observed a range in AA availability from soybean meal from $31.3 \%$ for Met to $40.4 \%$ for Thr, and from $50.2 \%$ for Val to $71.9 \%$ for Met for heat-treated soybean meal using in situ methods. However, using an in vivo method Titgemeyer et al. (1989) reported that the AA availability of soybean meal varied from $27.2 \%$ for His to 70.85 for Arg. The latter values are more consistent with our in vivo observations. The variance is likely caused by different techniques and feed sources. The current isotope technique was found to be accurate and unbiased by Estes et al. (2018) using casein infusions; thus the inconsistent results from in situ and in vitro tests may indicate the inaccuracy of those evaluation methods.

Total EAA Availability from In Vivo, In Situ, and In Vitro Evaluations of Test Ingredients

Estimates of least squares means of total RUP-EAA availability are displayed in Table 6. The plasma EAA entry rates derived from our in vivo technique were $30.6,27.4,31.3,37.2,26.4,37.8$, and $33.5 \%$ of EAA in test ingredients for corn silage, grass hay, alfalfa hay, dried distillers grain, soyhulls, brewers grain, and corn grain, respectively. If we assume $8.27 \%$ utilization by gut tissue, EAA absorbed from the gut lumen (availability) were 33.4, 29.9, 34.1, 40.6, 28.8, 41.2, and $36.5 \%$ of EAA in test ingredients. Previous mobile bag studies found that the average TAA availability of RUP for corn silage, grass hay, alfalfa hay, dried distillers grain, soyhulls, brewers grain, and corn grain were 32.7, $28.5,26,52.1,26.0,45.3$, and $35.5 \%$ of $\mathrm{CP}$ in feed ingredients, respectively (NRC, 2001; White et al., 2017b), which is similar to our in vivo results. However, the in vitro and in situ results from single feed ingredients and time points showed great variation. Compared with in vivo results, in vitro tests tended to give lower RUP digestibility for hay and higher values for other feedstuffs, which was inconsistent with previous observations (Berthiaume et al., 2000; Jahani-Azizabadi et al., 2009). The potential reason is that in vitro conditions may not perfectly mimic the animal digestion system. The RUP availability from in situ tests in the current study is less than the in vivo results. Berthiaume et al. (2000) compared in situ and in vivo methods for intestinal digestibility of rumen-protected Met and also found that in situ techniques underestimated Met availability ( $43.6 \%$ vs. $74.5 \%$ ), which was hypothesized to be caused by the restricting contact between test feed and duodenal chyme. But this may not be the case for other amino acids, and discrepancy exists among studies. Jahani-Azizabadi et al. (2009) found that in vivo totaltract nitrogen disappearance was less than indicated by in situ and in vitro methods. This could be due to lack of correction factors for endogenous CP and large intestinal microbial fermentation. The variation might also be due to animal, diets, AA, or methods (White et al., 2017b). The in vivo method should be the most reliable, because all measurements occur naturally within the animal's body. Therefore, it is critical to compare non-in vivo methods with valid in vivo methods across ingredients to verify the in vitro or in situ approaches before application. However, the cost of in vivo work makes it less applicable as a commercial technique. Although White et al. (2017b) compared mobile bags and in vitro methods for RUP digestibility and found 
Table 6. Least squares means of protein entry rates predicted from entry of Ile, Leu, Met, Lys, Phe, Thr, and Val for each ingredient, and calculated digestible RUP and digestibility of RUP for each ingredient

\begin{tabular}{|c|c|c|c|c|c|c|}
\hline Ingredient & $\begin{array}{c}\text { Plasma EAA } \\
\text { availability, } \\
\text { \% ingredient } \\
\text { EAA }\end{array}$ & SEM & $\begin{array}{l}\text { RUP-EAA } \\
\text { availability, } \\
\text { \% ingredient } \\
\text { EAA }\end{array}$ & $\begin{array}{c}\text { RUP-TAA } \\
\text { availability, } \\
\text { \% CP }\end{array}$ & $\begin{array}{c}\text { RUP-TAA } \\
\text { availability, }^{3} \\
\% \mathrm{CP}\end{array}$ & $\begin{array}{c}\text { RUP-TAA } \\
\text { availability, } \\
\% \mathrm{CP}\end{array}$ \\
\hline Corn silage & 30.6 & 3.4 & 33.4 & 55.1 & 11.1 & 32.7 \\
\hline Grass hay & 27.4 & 3.2 & 29.9 & 11.4 & 11.7 & 28.5 \\
\hline Alfalfa hay & 31.3 & 3.4 & 34.1 & 20.6 & 11.5 & 26.0 \\
\hline Dried distillers grain & 37.2 & 3.2 & 40.6 & 44.6 & 21.4 & 52.1 \\
\hline Soyhulls & 26.4 & 3.2 & 28.8 & 55.9 & 17.4 & 26.0 \\
\hline Brewers grain & 37.8 & 3.2 & 41.2 & 40.9 & 25.3 & 45.3 \\
\hline Corn grain & 33.5 & 3.2 & 36.5 & 62.3 & 29.4 & 35.5 \\
\hline
\end{tabular}

${ }^{1}$ Values calculated from plasma AA availability and $8.27 \%$ utilization of AA by gut tissue during absorption (Estes et al., 2018).

${ }^{2}$ Total AA availability of RUP from in vitro results: RUP-TAA availability $(\% \mathrm{CP})=\mathrm{RUP}(\% \mathrm{CP}) \times$ RUP digestibility $(\%) / 100$.

${ }^{3}$ Total AA availability of RUP from in situ results.

${ }^{4}$ Total AA availability of RUP calculated from RUP and its digestibility reported by White et al. (2017b).

more variation associated with the use of mobile bags, we found that the mean for mobile bag RUP and digested RUP were similar to our estimates calculated from AA availability and thus are potentially useful for assessment of variation among sources. However, that method is subject to potential bias associated with the choice of residence time in the rumen, where appropriate times likely vary by ingredient.

\section{Future Work}

In the future, more feed ingredients can be tested using this method. To obtain results with standard errors less than $15 \%$ on a relative basis, the dietary true protein proportion contributed by the test ingredient should not be less than $12.1 \%$ of dietary CP. This will help decrease variation in the final EAA availability estimates and ensure robust entry rate derivation for the ingredient. Additional precision and reduced total entry rate bias may be achieved using an infusion time not less than $6 \mathrm{~h}$. The increased observation time will also reduce the chance of entry rate variation affecting the estimates, and will improve estimates of the true plateau state, which should allow derivation of more accurate and precise estimates of true plasma AA entry rates independent of the $\mathrm{BD}$ and a better understanding of protein turnover in the body.

Additionally, it may be possible to define the proportion of total EAA entry that is derived from digested $\mathrm{MCP}$ if microbes are labeled with ${ }^{15} \mathrm{~N}$ via ruminal ammonium sulfate infusion. Finally, the protein digestibility of feed ingredients is likely not consistent under different feeding conditions, such as very high or low $\mathrm{CP}$ and energy intakes (Yang and Beauchemin, 2004). In addition, ingredient source and degradability of dietary $\mathrm{CP}$ are also factors that may introduce variation among sources of a common ingredient (Prange et al., 1984; Mabjeesh et al., 1996; Kleinschmit et al., 2007). Therefore, additional work is required to assess the range in availabilities from different sources of an ingredient with different feeding conditions (e.g., high and low forage), and to further evaluate in situ and in vitro methods, compared with in vivo measurement, if we are to develop a real-time system that can be used by industry.

\section{CONCLUSIONS}

We observed EAA availability for corn silage, grass hay, alfalfa hay, distillers grain, soyhulls, brewers grain, and corn grain of $33.4,29.9,34.1,40.6,28.8,41.2$, and $36.5 \%$ of ingredient EAA, respectively, assuming $8.27 \%$ utilization by gut tissue. Although the general trend (availability of forage and byproducts lower than availability of grains) was consistent, compared with in vivo results, in vitro evaluations underestimated RUP availability of hay but overestimate other feedstuffs, whereas in situ methods underestimated RUP availability of all test ingredients. The average RUP availability derived from meta-analysis of mobile bag results are representative and can be used to evaluate variations among sources, but the availability of individual AA from in situ or in vitro vary less compared with in vivo values. Therefore, in vivo studies are necessary to build a matrix of EAA availabilities for representative ingredients that can be used in nutritional models.

\section{ACKNOWLEDGMENTS}

The authors acknowledge The Institute for Feed Education and Research, American Feed Industry Association (Arlington, VA) for funding this project. Huang was partially supported by the China Scholarship Council (Beijing, China). 


\section{REFERENCES}

AFIA. 2017. U.S. Animal Food Consumption Report. Accessed Aug. 31, 2019. https://www.afia.org/pub/?id=49AB0CF7-F3ED-766D -F8F0-82EEB09179C8.

Agle, M., A. Hristov, S. Zaman, C. Schneider, P. Ndegwa, and V. Vaddella. 2008. Effect of dietary protein level and degradability and energy density on ammonia losses from manure in dairy cows. J. Dairy Sci. 91:324.

Anderson, J. L., K. F. Kalscheur, A. D. Garcia, and D. J. Schingoethe. 2015. Feeding fat from distillers dried grains with solubles to dairy heifers: I. Effects on growth performance and total-tract digestibility of nutrients. J. Dairy Sci. 98:5699-5708.

Baker, D. H. 1996. Advances in amino acid nutrition and metabolism of swine and poultry. Page 41 in Nutrient Management of Food Animals to Enhance and Protect the Environment. E. T. Kornegay, ed. Lewis Publishers, Washington, DC.

Bateman, H. 2005. Response to increased rumen undegradable protein intake by lactating dairy cows. Prof. Anim. Sci. 21:263-271.

Bateman, H. G. 2nd, J. H. Clark, R. A. Patton, C. J. Peel, and C. G. Schwab. 2001. Accuracy and precision of computer models to predict passage of crude protein and amino acids to the duodenum of lactating cows. J. Dairy Sci. 84:649-664.

Berthiaume, R., H. Lapierre, M. Stevenson, N. Coté, and B. W. McBride. 2000. Comparison of the in situ and in vivo intestinal disappearance of ruminally protected methionine. J. Dairy Sci. 83:20492056. https://doi.org/10.3168/jds.S0022-0302(00)75086-7.

Borucki Castro, S. I., L. E. Phillip, H. Lapierre, P. W. Jardon, and R. Berthiaume. 2007. Ruminal degradability and intestinal digestibility of protein and amino acids in treated soybean meal products. J. Dairy Sci. 90:810-822. https://doi.org/10.3168/jds.S0022 $-0302(07) 71565-5$.

Boucher, S. E., S. Calsamiglia, C. M. Parsons, H. H. Stein, M. D Stern, P. S. Erickson, P. L. Utterback, and C. G. Schwab. 2009a. Intestinal digestibility of amino acids in rumen undegradable protein estimated using a precision-fed cecectomized rooster bioassay: I. Soybean meal and soyplus1. J. Dairy Sci. 92:4489-4498.

Boucher, S. E., S. Calsamiglia, C. M. Parsons, M. D. Stern, M. R. Moreno, M. Vázquez-Añón, and C. G. Schwab. 2009b. In vitro digestibility of individual amino acids in rumen-undegraded protein: The modified three-step procedure and the immobilized digestive enzyme assay1. J. Dairy Sci. 92:3939-3950.

Bouwman, L., K. K. Goldewijk, K. W. Van Der Hoek, A. H. Beusen, D. P. Van Vuuren, J. Willems, M. C. Rufino, and E. Stehfest. 2013. Exploring global changes in nitrogen and phosphorus cycles in agriculture induced by livestock production over the 1900-2050 period. Proc. Natl. Acad. Sci. USA 110:20882-20887.

Cabrita, A. R., R. J. Dewhurst, D. S. Melo, J. M. Moorby, and A. J. Fonseca. 2011. Effects of dietary protein concentration and balance of absorbable amino acids on productive responses of dairy cows fed corn silage-based diets. J. Dairy Sci. 94:4647-4656.

Calder, A. G., K. E. Garden, S. E. Anderson, and G. Lobley. 1999. Quantitation of blood and plasma amino acids using isotope dilution electron impact gas chromatography/mass spectrometry with u-13c amino acids as internal standards. Rapid Commun. Mass Spectrom. 13:2080-2083.

Cao, Z. J., J. L. Anderson, and K. F. Kalscheur. 2009. Ruminal degradation and intestinal digestibility of dried or wet distillers grains with increasing concentrations of condensed distillers solubles. J. Anim. Sci. 87:3013-3019.

Cochran, R., D. Adams, J. Wallace, and M. Galyean. 1986. Predicting digestibility of different diets with internal markers: Evaluation of four potential markers1. J. Anim. Sci. 63:1476-1483.

Colmenero, J. J., and G. A. Broderick. 2006. Effect of amount and ruminal degradability of soybean meal protein on performance of lactating dairy cows. J. Dairy Sci. 89:1635-1643.

Doepel, L., D. Pacheco, J. Kennelly, M. Hanigan, I. Lopez, and H. Lapierre. 2004. Milk protein synthesis as a function of amino acid supply. J. Dairy Sci. 87:1279-1297.

Doiron, K., P. Yu, J. J. McKinnon, and D. A. Christensen. 2009. Heatinduced protein structure and subfractions in relation to protein degradation kinetics and intestinal availability in dairy cattle. J. Dairy Sci. 92:3319-3330. https://doi.org/10.3168/jds.2008-1946.

Edmunds, B., K.-H. Südekum, R. Bennett, A. Schröder, H. Spiekers, and F. Schwarz. 2013. The amino acid composition of rumenundegradable protein: A comparison between forages. J. Dairy Sci. 96:4568-4577.

Estes, K. A., R. R. White, P. S. Yoder, T. Pilonero, H. Schramm, H. Lapierre, and M. D. Hanigan. 2018. An in vivo stable isotopebased approach for assessment of absorbed amino acids from individual feed ingredients within complete diets. J. Dairy Sci. 101:7040-7060.

Estes, K. A. 2017. Assessing intestinal absorption of amino acids utilizing an isotope based approach. MS Thesis. Department of Dairy Science, Virginia Polytechnic Institute and State University, Blacksburg. http://hdl.handle.net/10919/84352.

Garlick, P. J., M. A. McNurlan, and V. R. Preedy. 1980. A rapid and convenient technique for measuring the rate of protein synthesis in tissues by injection of [3h] phenylalanine. Biochem. J. 192:719-723.

Graulet, B., C. Richard, and J. Robert. 2005. Methionine availability in plasma of dairy cows supplemented with methionine hydroxy analog isopropyl ester. J. Dairy Sci. 88:3640-3649.

Hanigan, M. D., J. France, S. J. Mabjeesh, W. C. McNabb, and B. J. Bequette. 2009. High rates of mammary tissue protein turnover in lactating goats are energetically costly. J. Nutr. 139:1118-1127.

Haque, M. N., H. Rulquin, A. Andrade, P. Faverdin, J. L. Peyraud, and S. Lemosquet. 2012. Milk protein synthesis in response to the provision of an "ideal" amino acid profile at 2 levels of metabolizable protein supply in dairy cows. J. Dairy Sci. 95:5876-5887. https://doi.org/10.3168/jds.2011-5230.

Ipharraguerre, I. R., J. H. Clark, and D. E. Freeman. 2005. Rumen fermentation and intestinal supply of nutrients in dairy cows fed rumen-protected soy products. J. Dairy Sci. 88:2879-2892.

Jahani-Azizabadi, H., M. Danesh Mesgaran, R. Valizadeh, and H. Nassiri Moghaddam. 2009. Comparison of in vivo with in situ mobile bag and three step enzymatic procedures to evaluate protein disappearance of alfalfa hay and barley grain. Majallah-i Tahqiqat-i Dampizishki-i Iran 10:260-266.

Janicki, F. J., and C. C. Stallings. 1988. Degradation of crude protein in forages determined by in vitro and in situ procedures. J. Dairy Sci. 71:2440-2448. https://doi.org/10.3168/jds.S0022 -0302(88)79829-X.

Kebreab, E., A. Strathe, J. Dijkstra, J. A. Mills, C. K. Reynolds, L. A. Crompton, T. Yan, and J. France. 2010. Energy and protein interactions and their effect on nitrogen excretion in dairy cows. Pages 417-425 in Proceedings of the 3rd EAAP International Symposium on Energy and Protein Metabolism and Nutrition Parma. EAAP Scientific Series, Volume 127. G. M. Crovetto ed. Italy.

Kleinschmit, D. H., J. L. Anderson, D. J. Schingoethe, K. F. Kalscheur, and A. R. Hippen. 2007. Ruminal and intestinal degradability of distillers grains plus solubles varies by source. J. Dairy Sci. 90:2909-2918. https://doi.org/10.3168/jds.2006-613.

Külling, D., H. Menzi, T. Kröber, A. Neftel, F. Sutter, P. Lischer, and M. Kreuzer. 2001. Emissions of ammonia, nitrous oxide and methane from different types of dairy manure during storage as affected by dietary protein content. J. Agric. Sci. (Belihuloya) 137:235-250.

Mabjeesh, S. J., A. Arieli, I. Bruckental, S. Zamwell, and H. Tagari. 1996. Effect of type of protein supplementation on duodenal amino acid flow and absorption in lactating dairy cows. J. Dairy Sci. 79:1792-1801.

Madsen, J., and T. Hvelplund. 1985. Protein degradation in the rumen. Acta Agric. Scand. 25:103.

Maxin, G., D. Ouellet, and H. Lapierre. 2013. Ruminal degradability of dry matter, crude protein, and amino acids in soybean meal, canola meal, corn, and wheat dried distillers grains. J. Dairy Sci. 96:5151-5160

Michalet-Doreau, B., and P. Cerneau. 1991. Influence of foodstuff particle size on in situ degradation of nitrogen in the rumen. Anim. Feed Sci. Technol. 35:69-81.

Michalet-Doreau, B., and M. Ould-Bah. 1992. In vitro and in sacco methods for the estimation of dietary nitrogen degradability in the rumen: A review. Anim. Feed Sci. Technol. 40:57-86. 
Mjoun, K., K. F. Kalscheur, A. R. Hippen, and D. J. Schingoethe. 2010. Ruminal degradability and intestinal digestibility of protein and amino acids in soybean and corn distillers grains products. J. Dairy Sci. 93:4144-4154. https://doi.org/10.3168/jds.2009-2883.

Nahm, K. 2002. Efficient feed nutrient utilization to reduce pollutants in poultry and swine manure. Crit. Rev. Environ. Sci. Technol. $32: 1-16$.

NRC. 2001. Nutrient Requirements of Dairy Cattle. 7th rev. ed. Natl. Acad. Press, Washington, DC.

Oldham, J. 1987. Testing and implementing the modern systems: UK. Pages 269-281 in Feed Evaluation and Protein Requirements for Ruminants. Office for Official Publications of the European Communities, Luxembourg.

Ørskov, E., and I. McDonald. 1979. The estimation of protein degradability in the rumen from incubation measurements weighted according to rate of passage. J. Agric. Sci. (Belihuloya) 92:499-503.

Paz, H. A., T. J. Klopfenstein, D. Hostetler, S. C. Fernando, E. Castillo-Lopez, and P. J. Kononoff. 2014. Ruminal degradation and intestinal digestibility of protein and amino acids in high-protein feedstuffs commonly used in dairy diets. J. Dairy Sci. 97:64856498. https://doi.org/10.3168/jds.2014-8108.

Prange, R., M. Stern, N. Jorgensen, and L. Satter. 1984. Site and extent of protein digestion in lactating cows fed alfalfa silage or baled alfalfa hay. J. Dairy Sci. 67:2308-2314.

Roman-Garcia, Y., R. R. White, and J. L. Firkins. 2016. Meta-analysis of postruminal microbial nitrogen flows in dairy cattle. I. Derivation of equations. J. Dairy Sci. 99:7918-7931.

Rutherfurd, S. M., and P. Moughan. 1998. The digestible amino acid composition of several milk proteins: Application of a new bioassay. J. Dairy Sci. 81:909-917.

Setälä, J. 1983. The nylon bag technique in the determination of ruminal feed protein degradation. Agric. Food Sci. 55:1-78.

Taghizadeh, A., M. D. Mesgaran, R. Valizadeh, F. E. Shahroodi, and K. Stanford. 2005. Digestion of feed amino acids in the rumen and intestine of steers measured using a mobile nylon bag technique. J. Dairy Sci. 88:1807-1814.

Titgemeyer, E. C., N. R. Merchen, and L. L. Berger. 1989. Evaluation of soybean meal, corn gluten meal, blood meal and fish meal as sources of nitrogen and amino acids disappearing from the small intestine of steers. J. Anim. Sci. 67:262-275.

USDA. 2017. Agricultural statistics. United States Department of Agriculture, National Agricultural Statistics Service, United States Government Printing Office, Washington, DC.

van Straalen, W. M., J. J. Odinga, and W. Mostert. 1997. Digestion of feed amino acids in the rumen and small intestine of dairy cows measured with nylon-bag techniques. Br. J. Nutr. 77:83-97.

Varvikko, T. and A. Vanhatalo. 1991. Intestinal nitrogen degradation of hay and grass silage estimated by the mobile bag technique. World Rev. Anim. Prod. 26:73-76.

Walsh, R. G., S. He, and C. T. Yarnes. 2014. Compound-specific $\delta 13 c$ and $\delta 15 \mathrm{n}$ analysis of amino acids: A rapid, chloroformate-based method for ecological studies. Rapid Commun. Mass Spectrom. 28:96-108.https://doi.org/10.1002/rcm.6761.

White, R. R., Y. Roman-Garcia, J. L. Firkins, P. Kononoff, M. J VandeHaar, H. Tran, T. McGill, R. Garnett, and M. D. Hanigan. 2017a. Evaluation of the National Research Council (2001) dairy model and derivation of new prediction equations. 2. Rumen degradable and undegradable protein. J. Dairy Sci. 100:3611-3627.

White, R. R., P. J. Kononoff, and J. L. Firkins. 2017b. Technical note: Methodological and feed factors affecting prediction of ruminal degradability and intestinal digestibility of essential amino acids. J. Dairy Sci. 100:1946-1950. https://doi.org/10.3168/jds.2016-12008.

Whitehouse, N., C. Schwab, S. Fredin, and A. Brito. 2016. Determination of relative methionine bioavailability in lactating cows fed Smartamine M, Mepron, and Aminoshure M using the plasma-free aa dose-response method. J. Anim. Sci. 94:776-777.

Yang, W. Z., and K. A. Beauchemin. 2004. Grain processing, forage-to-concentrate ratio, and forage length effects on ruminal nitrogen degradation and flows of amino acids to the duodenum. J. Dairy Sci. 87:2578-2590. https://doi.org/10.3168/jds.S0022 -0302(04)73383-4.

Zhang, B., C. Wang, H. Liu, J. Liu, and H. Liu. 2017. Effects of dietary protein level on growth performance and nitrogen excretion of dairy heifers. Asian-Australas. J. Anim. Sci. 30:386. 